\title{
Стратегические приоритеты экономического развития и «ресурсная экономика» Дальневосточного макрорегиона
}

\author{
Н.В. ЛОМАКИНА, доктор экономических наук, Институт экономических \\ исследований ДВО РАН, Хабаровск. E-mail:. Iomakina@ecrin.ru
}

\begin{abstract}
Аннотация. В статье на основе анализа стратегических документов развития регионов Дальневосточного федерального округа выявлены структурные приоритеты и отрасли-драйверы их экономического роста. Показано, что на перспективу в 15-20 лет для большинства территорий макрорегиона ключевыми направлениями и основными драйверами развития остаются ресурсные отрасли, прежде всего минеральный сектор. При этом приведены некоторые социально-экономические показатели, отражающие недостаточность вклада ресурсного сектора в качество жизни и экономического роста на Дальнем Востоке. Для повышения эффективности использования минеральных ресурсов как фундаментального и конкурентного фактора развития региона предложено изменение акцентов современной государственной политики в минеральном секторе Дальневосточного макрорегиона с поддержки добычи ресурсов на стимулирование создания высокотехнологичных производств, базирующихся на их использовании. Кроме прочего, такие производства могут стать основой международных центров сотрудничества и реальной кооперации в Северо-Восточной Азии. Такие подходы могли бы обеспечить более тонкую увязку объективных возможностей развития региона с приоритетами формируемой Национальной программы для Дальнего Востока и повышением качества экономического роста, вклада минеральных ресурсов в социально-экономическое развитие региона.
\end{abstract}

Ключевые слова: Дальневосточный макрорегион; стратегии развития; структурные приоритеты; отрасли специализации; драйверы роста; качество развития; минеральный сектор; горнодобывающая промышленность; потенциал развития

\section{Введение}

Современный этап формирования и реализации документов стратегического планирования Дальневосточного макрорегиона' ${ }^{1}$, определяющих приоритеты его перспективного развития,

\footnotetext{
${ }^{1}$ Термин «Дальневосточный макрорегион» применяется в соответствии со Стратегией пространственного развития РФ на период до 2025 г., утвержденной распоряжением Правительства РФ от 13.02.2019 г. № 207-р. В его состав входят 11 субъектов РФ. Также в статье в качестве синонима употребляется «Дальневосточный федеральный округ» (ДФО) с аналогичным составом субъектов РФ в соответствии с Указом Президента РФ от 03.11.2018 № 632 «О внесении изменений в перечень федеральных округов, утвержденный Указом Президента Российской Федерации от 13 мая 2000 г. № 849 ».
} 
характеризуется, с одной стороны, утверждением стратегий регионального уровня практически для всех входящих в него субъектов РФ, а с другой - формированием нового стратегического документа для всего макрорегиона. Речь идет о Национальной программе развития Дальнего Востока на период до 2025 года и на перспективу до 2035 года. Заявляется, что в нее будут «погружены» все уже работающие инструменты: стратегии дальневосточных субъектов РФ, национальные проекты и отраслевые программы с выделением специальных разделов по Дальневосточному макрорегиону. Национальная программа должна обеспечить прорывные решения, результатами которых предполагаются темпы роста экономики ДФО выше среднемировых (минимум 6\% в год), рост численности и приток (вместо нынешнего оттока) населения в регион, высокое качество жизни в нем. Решение таких амбициозных задач должно чем-то обеспечиваться. Например, выстроенными приоритетами перспективного экономического развития дальневосточных регионов, выявлением отраслей-драйверов роста.

В условиях, когда экономика большинства субъектов Дальневосточного макрорегиона приобретает всё более «сырьевой» характер, вызывает интерес вопрос о том, предполагается ли в контексте реализуемой государственной политики изменение «траектории» их развития? И если - да, то насколько они фундаментальны? Остаются ли сырьевые отрасли драйверами роста для этих экономик на перспективу? Некоторым размышлениям по этому поводу посвящена предлагаемая работа.

\section{Структурные приоритеты экономического развития: региональный срез}

Как показывают исследования тенденций развития дальневосточных регионов [Российский Дальний ..., 2017; Глазырина и др., 2018], а также субъектов РФ, недавно включенных в округ - Забайкальского края и Республики Бурятия [Природный капитал..., 2014], «стабилизаторами» в кризисные времена и «драйверами» в периоды подъемов экономики стали для макрорегиона отрасли ресурсного сектора. Отдельные из них имели в течение периода реформ разную (а зачастую и разнонаправленную) динамику [Антонова и др., 2017], однако в це- 
лом роль этого сектора (и, прежде всего, горнодобывающего комплекса) в дальневосточной экономике определенно возросла [Российский Дальний ..., 2017; Минерально-сырьевой ..., 2015]. Оценка первых результатов реализации «новой модели» развития макрорегиона в его ресурсном секторе [Антонова, Ломакина, 2018], мониторинг инвестиционной активности входящих в него отраслей [Ломакина, 2018] подтверждают его всевозрастающее значение.

При этом амбициозность заявленных на национальном уровне задач перспективного развития макрорегиона, вероятно, требует качественных изменений как в источниках, так и в направлениях ускоренного экономического роста. В связи с этим, на наш взгляд, представляет интерес «региональный срез» перспективных структурных приоритетов экономического развития, сформированных в субъектах ДФО.

Регионы с сырьевой специализацией. В течение многих десятилетий «экономическое лицо» Дальнего Востока определяют ресурсные отрасли, и прежде всего горнодобывающая промышленность. Ключевыми территориями, минерально-сырьевой комплекс которых определяет экономическое развитие не только на региональном, но и на федеральном уровне, являются Республика Саха (Якутия), Чукотский автономный округ, Магаданская область. Нет оснований полагать, что в ближайшей перспективе их значение изменится. Тем не менее интересно посмотреть, как сами территории определяют траектории своего развития в официально принятых документах стратегического планирования.

«Стратегия ...»² развития одной из самых крупных экономик Дальневосточного макрорегиона - Республики Саха (Якутии), прямо констатирует, что «усиливается сырьевая экспортно ориентированная модель экономики республики, зависимость от добычи полезных ископаемых». Доля вида экономической деятельности (вэд) «Добыча полезных ископаемых» в ВРП региона в 2015 г. составила 45,2\% (при средней по РФ 10,4\%), в том числе 20,1\% - это вклад алмазодобывающей промышленности. Добыча

\footnotetext{
${ }^{2}$ Стратегия социально-экономического развития Республики Саха (Якутия) на период до 2030 года с определением целевого видения до 2050 года. Якутск, 2016. [Эл. ресурс] // Министерство экономического развития РФ. Официальный сайт. URL: http:/economy.gov.ru/minec/activity/sections/strategterplanning/komplstplanning/stsubject/ straterupdate (дата обращения: 16.02.2019).
} 
полезных ископаемых формирует 80\% объема промышленного производства и более $60 \%$ налоговых доходов консолидированного бюджета республики.

По оценке региональных органов управления, «до 2030 года промышленное освоение природных ресурсов сохранит свою роль в качестве основного источника экономического роста - как по создаваемой стоимости, так и благодаря масштабному вкладу в технологические инновации и повышение производительности». При сохранении лидирующей роли алмазодобычи непростые задачи на перспективу ставятся и для добычи драгоценных и цветных металлов. Так, добыча золота к 2030 г. должна вырасти с нынешних 28 до 38 т, серебра - до 629 т. Особые задачи стоят по реальному освоению месторождений редкоземельных металлов и формированию основ для появления в регионе новой высокотехнологичной отрасли [Самсонов, 2018]. Условием такого развития горнодобывающего комплекса является соответствующая технологическая модернизация «с расширенной сервисной средой при рациональном природопользовании и высокой социальной ответственности бизнеса».

Вложения в добывающий комплекс по-прежнему будут определять инвестиционную активность на территории, что косвенно подтверждается и прогнозом достаточно скромной доли в общем объеме инвестиций «перерабатывающего сектора экономики и сектора будущего (креативные и инновационные)»-рост её составит лишь 3\% за 15 лет (с 17\% в 2015 г. до 20\% в 2030 г.).

Таким образом, более чем на десятилетний период основой экономики Республики Саха и драйверами её роста остаются добывающие отрасли.

Базовой отраслью экономики Магаданской области также является горнодобывающая промышленность (главным образом - добыча драгоценных металлов), которая в 2010-2017 гг. стала основой устойчивой динамики развития региона (среднегодовой темп прироста его промышленного производства за этот период составил 106,1\%). Главными целями социально-экономического развития Магаданской области на период до 2030 года региональная «Стратегия...» провозглашает «обеспечение ускоренного устойчивого экономического развития... сохранение и развитие человеческого капитала». При этом «добыча полезных ископаемых будет продолжать играть ключевую роль 
в экономике региона и в долгосрочной перспективе» ${ }^{3}$. Так, объем золотодобычи в 2025 г. прогнозируется на уровне около 50 т (против 36,8 т в 2018 г.) ${ }^{4}$. При этом до половины всего золота может обеспечить добыча на двух крупнейших месторождениях - Наталка и Павлик. Добыча серебра, напротив, несколько снизится (с 660 до 550 т в период 2018-2030 гг.). Кроме того, сохраняются планы и надежды региональной власти на реальное освоение месторождений цветных металлов.

Горнодобывающая промышленность является отраслью национальной специализации и для Чукотского автономного округа. При этом её роль в региональной экономике возрастает: так, если в 2005 г. доля добычи полезных ископаемых в общем объеме промышленного производства региона лишь немногим превышала 40\%, то уже в 2016 г. она составила 88,7\% [Ломакина, 2018]. Стратегическое развитие Чукотки на период до 2030 г. ${ }^{5}$ также определяется освоением ресурсных месторождений, прежде всего - сконцентрированных в двух промышленных зонах: Анадырской (каменный уголь, нефть и газ) и Чаун-Билибинской (золото, серебро, олово и медь). Цветная металлургия и угольная промышленность станут основными драйверами развития экономики региона. По прогнозу региональных органов управления, доля добывающей промышленности в отраслевой структуре валовой добавленной стоимости региона к 2030 г. составит 57\%. При этом планируется, что общий объем добычи золота уже к 2025 г. достигнет 40-43 т (при фактической добыче в 2018 г. чуть более $\left.24 \mathrm{~T}^{6}\right)$.

Еще одной дальневосточной территорией, основа экономики которой - использование природных ресурсов, является

${ }^{3}$ Стратегия социально-экономического развития Магаданской области на период до 2030 года. Магадан, 2018. [Эл. ресурс] // Министерство экономического развития РФ. Официальный сайт. URL: http://economy.gov.ru/minec/activity/sections/strategterplanning/ komplstplanning/stsubject/straterupdate (дата обращения: 16.02.2019).

${ }^{4}$ URL: http://zolteh.ru/news/zolotodobytchiki-magadanskoj-oblasti-dobyli-36-8-tonnmetalla/

16.01.2019 (дата обращения: 23.03.2019).

5 «Стратегия социально-экономического развития Чукотского автономного округа до 2030 года». Утв. расп. Правительства Чукотского автономного округа 16.07.2014 г. № 290-рп. [Эл. ресурс] // Правительство Чукотского автономного округа. Официальный сайт. URL: https://invest-chukotka.ru/investpolitika/investiczionnaya-strategiya (дата обращения: 15.03.2019).

${ }^{6}$ URL: https://www.vestifinance.ru/articles/113006 (дата обращения: 23.03.2019). 
Сахалинская область. Полезные ископаемые, биологические ресурсы морей и суши составляют её конкурентный потенциал. Однако доминирующее положение в структуре промышленного производства Сахалинской области занимает нефтегазовый комплекс. На его долю приходится около $85 \%$ общего объема промышленного производства, более 70\% налоговых доходов областного бюджета и 90\% экспорта (по итогам 2016 г.). В принятой Стратегии ${ }^{7}$ развития территории до 2025 г. среди круга целевых задач обозначены, конечно, и «диверсификация экономики, и обеспечение ее конкурентоспособности», и «концентрация усилий на развитии ненефтегазового сектора региональной экономики». Однако объективно в период до 2025 г. основу сахалинской промышленности и экспорта по-прежнему будет составлять нефтегазовый сектор, сохраняя за собой позицию как драйвера роста экономики в целом, так и источника социальноэкономического развития территории.

К территориям с всё возрастающим значением минеральносырьевого комплекса в экономике относятся Забайкальский край и Амурская область.

Минерально-сырьевой потенциал является главным конкурентным преимуществом Забайкалья, добыча полезных ископаемых и цветная металлургия - базовые виды деятельности в структуре его промышленности. При этом «Стратегия...» развития региона ${ }^{8}$ определяет, что «горнорудная промышленность, основанная на глубокой переработке сырья, в перспективе ближайших 10-15 лет будет исполнять роль «локомотива территориального развития, имеющего глобальное значение для экономики и финансов региона». В целом в перспективе до 2030 года «Стратегия...» предусматривает трехкратный рост объемов добычи полезных ископаемых, что должно быть

${ }^{7}$ «Стратегия социально-экономического развития Сахалинской области на период до 2025 года». Утверждена постановлением Правительства Сахалинской области от 28.03.2011 №99. (в ред. Постановлений Правительства Сахалинской области от 22.01.2018 №21, от 05.03.2018 № 75). [Эл. ресурс] // Правительство Сахалинской области. Официальный сайт. URL: https://sakhalin.gov.ru/index.php?id=139 (дата обращения 06.04.2019).

${ }^{8}$ Стратегия социально-экономического развития Забайкальского края на период до 2030 года (в ред. пост. Правительства Забайкальского края № 122 от 05.04.2016). Чита, 2016. [Эл. ресурс] // Правительство Забайкальского края. Официальный сайт. URL: http:/правительство.забайкальскийкрай.pф/action/programs/strategiya-socialnoekonomicheskogo-razvitiya-zabaykalskogo-kraya/ (дата обращения: 20.02.2019). 
обеспечено поддержанием ежегодного прироста объема инвестиций в этот комплекс на уровне 6-7\%. Прогнозные темпы роста ресурсного сектора «подпирают» и соответствующие индексы по промышленности, обеспечивая ожидания в целом позитивной динамики результирующих показателей экономики Забайкальского края9. При этом реализация проектов в горнорудной промышленности ориентирована на внешний, прежде всего, международный рынок.

Амурская область относится к регионам, в экономике которых роль минерального сектора всегда была значимой (в том числе и для общенационального уровня), хотя и не определяющей. Однако в последние 10-15 лет доля добывающего сектора в структуре региональной промышленности демонстрирует существенный рост: с 24,9\% в 2005 г. до 51,1\% в 2016 г. Как результат, вид деятельности «Добыча полезных ископаемых» в 2017 г. достиг почти 12\% ВРП Амурской области и стал вторым по значимости в его структуре после транспорта $(16,7 \%)^{10}$. Основная специализация сектора - добыча золота $(85,9 \%$ в общем объеме выпуска по итогам в 2016 г.).

Задача «формирования высокотехнологичного инновационного добывающего комплекса полного цикла (начиная с добычи, обогащения до производства конечного продукта) с высоким уровнем комплексного извлечения и глубокой переработкой» является одной из ключевых, обеспечивающих достижение стратегических целей социально-экономического развития Амурской области до 2025 года ${ }^{11}$. Оптимальный сценарий «Стратегии...» относительно развития ресурсных отраслей характеризуется «реализацией крупных инвестиционных проектов, обеспечивающих увеличение добычи полезных ископаемых на осваиваемых

9 Показатели прогноза социально-экономического развития Забайкальского края на долгосрочный период. [Эл. ресурс] // Правительство Забайкальского края. Официальный сайт. URL: http:/правительство.забайкальскийкрай.pф/action/programs/ prognoz-socialno-ekonomicheskogo-razvitiya-zabaykalskogo-kraya/ (дата обращения: 24.03.2019).

${ }^{10}$ Рассчитано с использованием официальной информации Амурстата. URL: http://amurstat.gks.ru/wps/wcm/connect/rosstat_ts/amurstat/resources/5309f580434ele2bbc dfbe584a73b591/02_1_2.htm (дата обращения: 24.03.2019).

${ }^{11}$ Стратегия социально-экономического развития Амурской области на период до 2025 года (в ред. пост. Правительства Амурской области от 08.11.2017 № 529). С. 43. [Эл. ресурс] // Правительство Амурской области. Официальный сайт. URL: http://mer. amurobl.ru/ru/sections/53 (дата обращения: 20.02.2019). 
и новых месторождениях, их привязкой к транспортным магистралям области; повышением продуктивности и эффективности использования месторождений за счет внедрения новых технологий». Как результат - дальнейшее увеличение доли ресурсного сектора в структуре экономики. К приоритетным направлениям относятся формирование горно-металлургического кластера с развитием добычи и переработки железной руды, угля, золота, никеля.

Регионы с формирующейся сырьевой специализацией. К таким регионам относятся Еврейская автономная область и Камчатский край, в которых реализуются сравнительно крупные минеральные проекты, влияющие на экономическую специализацию этих территорий. Насколько эти изменения «фундаментальны»? Остаются ли сырьевые отрасли драйверами роста для этих экономик на перспективу?

Официально закрепленная миссия «Стратегии...» Еврейской автономной области (ЕАО) заключается в «обеспечении для населения области к 2030 году высокого качества жизни и удвоения по сравнению с существующим уровнем величины реальных располагаемых доходов населения при высокой степени доступности качественных социальных и коммунальных услуг, комфортной среды обитания». При этом генеральной стратегической целью, обеспечивающей реализацию этой миссии, определяется «создание эффективной экономической системы... интегрированной в сеть межрегиональных и международных отношений и являющейся базисом для роста благосостояния и качества жизни населения области» ${ }^{12}$. Ключевые экономические комплексы должны стать драйверами экономического роста, обеспечивающими мультипликативный эффект развития всей экономики. Первым из них в Стратегии ЕАО назван горнопромышленный комплекс, «при условии формирования на основе местной сырьевой базы цепочек добавленной стоимости в смежных отраслях».

Если в 2005 г. доля «добычи полезных ископаемых» в структуре промышленности ЕАО составляла только 0,3\%, то к 2016 г. она возросла до 36,4\%. В 2017 г. было завершено строительство

\footnotetext{
${ }^{12}$ Стратегия социально-экономического развития Еврейской автономной области на период до 2030 года. Биробиджан, 2018. [Эл. ресурс] // Министерство экономического развития РФ. Официальный сайт. URL: http://economy.gov.ru/minec/activity/sections/ strategterplanning/komplstplanning/stsubject/straterupdate (дата обращения: 16.02.2019).
} 
и начат эксплуатационный этап Кимкано-Сутарского ГОКа по добыче и обогащению железных руд, благодаря чему индекс производства по виду деятельности «Добыча полезных ископаемых» за год взлетел на 472,1\%. После выхода на проектную мощность таких резких скачков, конечно, не ожидается, но к концу стратегического периода объемы производства горнодобывающего комплекса превысят 50\% от общих объемов промышленного выпуска региона, и его доля в структуре ВРП преодолеет планку 10\% (против 1,7\% в 2015 г.). Кроме того, с наращиванием производственной деятельности КимканоСутарского ГОКа его продукция сформирует основную номенклатуру экспорта ЕАО (достигнув 65\% его общего объема). По сути, перспективное социально-экономическое развитие региона становится все более зависимым от деятельности ограниченного количества компаний, работающих главным образом в сырьевом секторе экономики.

Для Камчатского края также характерно возрастание значения горнодобывающей промышленности: ее вклад в объем промышленного выпуска за 2005-2016 гг. увеличился с 4,4 до $21,9 \%$. В региональной «Стратегии...» ${ }^{13}$ горнодобывающему сектору отводятся роли одного из важнейших направлений диверсификации экономики, фактора инфраструктурного развития территории и активного привлечения инвестиций. Среди целевых индикаторов «Стратегии...» в минерально-сырьевом комплексе называется привлечение в период 2015-2030 гг. около 20\% всех инвестиций. Степень геологической изученности территории должна возрасти с 60\% в 2018 г. до 90\% к 2030 г., объемы добычи золота - увеличиться до 18 т, платины - до 1 т. При этом особо подчеркивается важная для Камчатского края «освоенческая» функция минерального сектора, формирующего инфраструктурный каркас и рабочие места на новых территориях.

Регионы с диверсифицированной экономикой. В качестве одного из примеров такого региона рассмотрим Хабаровский край. Притом, что для него действительно характерна достаточно

\footnotetext{
${ }^{13}$ Стратегия социально-экономического развития Камчатского края до 2030 года. Петропавловск-Камчатский, 2017. [Эл. ресурс] // Министерство экономического развития РФ. Официальный сайт. URL: http://economy.gov.ru/minec/activity/sections/ strategterplanning/komplstplanning/stsubject/straterupdate (дата обращения: 16.02.2019).
} 
прогрессивная структура экономики, значение горнодобывающего комплекса в предшествующие 10-15 лет существенно возросло, и он играет значимую роль в стратегических приоритетах региона.

Генеральная цель социально-экономического развития края на период до 2030 г. определена как его превращение «в центральный полюс роста Дальнего Востока, лидирующий в области взаимообусловленного роста человеческого капитала, инновационной экономики, пространственной организации и международной кооперации», а среди ключевых задач, обеспечивающих ее достижение, обозначена модернизация традиционных отраслей, и прежде всего ресурсного сектора. В региональной «Стратегии...» традиционные ресурсные отрасли (прежде всего - горнодобывающая) рассматриваются в качестве «ключевых комплексов-драйверов роста, при этом технологически обновленные и конкурентоспособные на внутреннем и внешнем рынках» ${ }^{14}$.

Новые инвестпроекты по освоению минеральных ресурсов Хабаровского края имеют важное значение как для обеспечения инвестиционной активности в регионе, так и для формирования результирующих показателей развития его экономики. В частности, по оценке краевого Минэкономразвития, доля вида деятельности «Добыча полезных ископаемых» в структуре инвестиционного портфеля региона возрастет с 6\% в 2012 г. до 9\% в 2025 г., а реализация одного из крупнейших инвестпроектов (строительство ГОКа на Малмыжском золото-меднопорфировом месторождении) сформирует новую отрасль национальной специализации в горнодобывающем комплексе края - добычу и переработку меди. Из других значимых для экономики региона проектов можно назвать развитие второй очереди Амурского горно-металлургического комбината и освоение новых золоторудных месторождений.

Еще одним субъектом Дальневосточного макрорегиона, для которого характерны диверсифицированная структура экономики с преимущественной ориентацией на машиностроение

\footnotetext{
${ }^{14}$ Стратегия социально-экономического развития Хабаровского края на период до 2030 года. Хабаровск, 2018. [Эл. ресурс] // Министерство экономического развития РФ. Официальный сайт. URL: http://economy.gov.ru/minec/activity/sections/strategterplanning/ komplstplanning/stsubject/straterupdate (дата обращения: 16.02.2019).
} 
и значимой ролью горнодобывающего комплекса [Дондоков, 2018], является Республика Бурятия. Нынешний вклад горнодобывающей отрасли в экономику региона (около 6\% в ВРП) оценивается региональными властями как недостаточный и не соответствующий минерально-сырьевому потенциалу территории. Поэтому в «Стратегии ...» ${ }^{15}$ долгосрочного развития региона предусмотрен целый ряд мер, направленных как на реализацию действующих проектов по освоению месторождений (рудного и россыпного золота, урана, каменного и бурого угля, нефрита, кварцитов, строительного сырья), так и на продолжение работ по поиску и вовлечению в хозяйственный оборот новых месторождений полезных ископаемых. При этом, как свидетельствует анализ целевых показателей Стратегии, при абсолютном росте в течение 2017-2035 гг. как объемов производства в промышленности в целом (в 3,2 раза), так и по виду деятельности «Добыча полезных ископаемых» (в 3,1 раза), доля ресурсного сектора в общей структуре региональной экономики остаётся стабильной - на уровне $22-24 \%$.

Для позитивного развития горнодобывающего комплекса Республики Бурятия и роста его отдачи в обозримой перспективе важными факторами являются не только рост инфраструктурной доступности новых месторождений, но и гармонизация развития добычи полезных ископаемых с экологическими требованиями на Байкальской природной территории [Дондоков и др., 2019]. Особое значение это имеет при запуске новых инвестпроектов.

Еще одним субъектом РФ в Дальневосточном макрорегионе, для которого характерны диверсифицированная экономика и наличие существенного потенциала развития минерально-сырьевого комплекса, является Приморский край. Добывающие предприятия региона - лидирующие российские производители и экспортёры нескольких видов продукции, в том числе - с содержанием бора, вольфрамового, свинцового и германиевого концентрата. Однако в настоящее время сектор не является основным для экономики Приморского края, доля минерально-сырьевой продукции в ВРП

\footnotetext{
15 Стратегия социально-экономического развития Республики Бурятия на период до 2035 года. Улан-Удэ, 2019. [Эл. ресурс] // Министерство экономического развития РФ. Официальный сайт. URL: http://economy.gov.ru/minec/activity/sections/ strategterplanning/komplstplanning/stsubject/straterupdate (дата обращения: 16.02.2019).
} 
составляет чуть более $1 \%$. В рамках «Стратегии социально-экономического развития Приморского края на период до 2030 года» ${ }^{16}$ предусмотрены важные задачи по развитию сырьевого комплекса (в частности, трехкратного увеличения объёмов выпуска), однако он не относится к числу локомотивов перспективного экономического роста.

В целом же, как показывает наше исследование, на обозримую перспективу минерально-сырьевые проекты остаются драйверами экономического роста практически для всех субъектов РФ в Дальневосточном макрорегионе.

\section{Некоторые выводы и размышления}

Анализ официальных стратегических документов развития субъектов Дальневосточного макрорегиона свидетельствует, что на «глубину» 10-15 лет существенных структурных изменений в их экономиках не предполагается. По-прежнему в большинстве территорий макрорегиона ключевыми направлениями и основными драйверами развития остаются добывающие отрасли. Вполне естественно, что именно на них рассчитывают регионы с уже сложившейся ресурсной специализацией. Но и для таких территорий, как Хабаровский край, Республика Бурятия, Амурская область сырьевые отрасли представляют интерес как обеспечивающие существенный сегмент роста их экономик.

Исследование первых результатов реализации преференциальных мер государственной политики по формированию «новой модели» развития Дальнего Востока в 2014-2018 гг. также выявило противоречие между заявленными для макрорегиона на федеральном уровне целями ухода от сырьевой экономики и фактическими направлениями государственной поддержки (включая прямые субсидии из федерального бюджета) [Ломакина, 2018]. Сегодня в последовательности ресурсной цепочки «воспроизводство - добыча - переработка - конечное потребление» государственная поддержка в виде различных механизмов

\footnotetext{
${ }^{16}$ Стратегия социально-экономического развития Приморского края на период до 2030 года. Владивосток, 2018. [Эл. ресурс] // Министерство экономического развития РФ. Официальный сайт. URL: http://economy.gov.ru/minec/activity/sections/ strategterplanning/komplstplanning/stsubject/straterupdate (дата обращения 16.02.2019).
} 
и преференций направлена, как ни странно, на стимулирование добычи минеральных ресурсов.

На наш взгляд, государственная политика в отношении развития минерально-сырьевого комплекса на Дальнем Востоке требует перенесения акцентов с этапа добычи на стадии воспроизводства и (особенно) конечного потребления минеральных ресурсов в регионе. При этом речь идет, безусловно, о стимулировании производственного потребления, а не просто переработки. Результаты стимулирования перерабатывающей стадии воспроизводственного цикла в лесном комплексе ДФО с формированием его «примитивной» структуры хорошо известны [Антонова и др., 2017; Природный капитал..., 2014 и др.]. Необходимо стимулировать создание в регионе новых производств, в высокотехнологичных процессах которых будут востребованы как уже добываемые драгоценные металлы (золото, платина, и др.), так и (в перспективе) пока не добываемые здесь виды минеральных ресурсов (редкоземельные металлы, медь, никель).

Целью создания таких производств может быть не только получение высокотехнологичных продуктов для национального рынка, но и формирование в Дальневосточном макрорегионе международных высокотехнологичных центров [Бардаль и др., 2018], что вполне отвечает амбициозным целям Национальной программы развития Дальнего Востока на период до 2025 года и на перспективу до 2035 года. По сути, на наш взгляд, задача государственного стимулирования в том и состоит, чтобы «насаждать» такие производства в регионе. Однако пока преференции по-прежнему предполагаются главным образом в сфере добычи ресурсов $^{17}$.

Вопросы создания в макрорегионе условий для «разработки комплексного сценария освоения минерально-сырьевой базы, включающего планы развития производственной инфраструктуры и формирование пакетов инвестпредложений, реализующих различные этапы развития территории» [Глазырина, Лавлинский, 2018. С. 141], для инновационного развития минерального сектора и его перехода к формированию конечных переделов [Крюков и др., 2018], важны не только с позиции привлечения

17 Госдума РФ приняла в первом чтении законопроект, направленный на стимулирование добычи редких металлов. URL: http://www.metalinfo.ru/ru/ news/107111 18.02.2019 (дата обращения: 23.03.2019). 
инвестиций и обеспечения ускоренных темпов роста экономики. Как в теоретическом [Sachs, Warner, 1995; Gylfason et al, 1999; Дорошенко, Шеломенцев, 2015; Ресурсные регионы..., 2017 и др.], так и в прикладном плане [Минерально-сырьевой ..., 2015; Белан, Шмат, 2015 и др.] не теряют актуальности проблемы повышения вклада ресурсного сектора в социальноэкономическое развитие территорий и качество экономического роста.

У многих дальневосточных регионов инвестиции в добывающий сектор составляют основную долю в их общей структуре [Ломакина, 2018], однако имеющиеся оценки влияния количественных характеристик инвестиционного процесса на экономический рост за период 2011-2016 гг. показывают, что южные регионы Дальнего Востока и Якутия, лидируя по объему инвестиций, по инвестиционной отдаче ${ }^{18}$ оказались аутсайдерами. «На более высокие позиции Магаданской области, Камчатки и Чукотки, повидимому, повлияло значительное число работающих вахтовым методом» [Глазырина и др., 2018. С. 108].

Однако сам по себе рост ВРП, даже и среднедушевого, еще не определяет, как известно, качество экономического развития. Одним из измерителей успешности (либо неуспешности) экономической и социальной политики принято считать показатели бедности населения ${ }^{19}$. «Как фактор, отражающий социальноэкономическую ситуацию в том или ином регионе, он приобрел особую значимость в условиях повсеместного падения доходов» [Михеева, 2017. С. 162]. И здесь парадоксы налицо. Так, в Республике Саха (Якутия), являющейся лидером ДФО по масштабам и экономики в целом, и минерально-сырьевого комплекса, и размерам удельного ВРП (в 2016 г. - 903,6 тыс. руб. при общероссийском значении 472,2 тыс. руб.), уровень бедности населения в 2017 г. был одним из самых высоких в регионе (20,3\% против $13,2 \%$ среднероссийского). Хуже ситуация только в Еврейской $\mathrm{AO}(24,9 \%)$ и Забайкальском крае $(21,5 \%)$, что прослеживается

\footnotetext{
${ }^{18}$ В качестве «определенной характеристики «чувствительности» показателя ВРП к инвестиционным потокам» авторы используют показатель инвестиционной отдачи, рассчитываемый как «отношение подушевого ВРП к показателю подушевых инвестиций» [Глазырина и др., 2018. С. 106].

${ }^{19}$ Одним из измерителей уровня бедности является учитываемый официальной статистикой показатель доли населения с доходами ниже прожиточного минимума в общей численности населения (в \%).
} 
на протяжении уже многих лет ${ }^{20}$. «Влияние данного фактора на экономический рост проявляется через нарастание социальных проблем, увеличение расходов на социальную поддержку населения, снижение качества человеческого капитала региона» [Михеева, 2017. С. 169].

К числу важнейших условий стабильности экономического роста относится и «экономическое самочувствие» предприятий региона, отражаемое показателем доли убыточных организаций в их общем количестве [Михеева, 2017]. Практически во всех «сырьевых» субъектах Дальнего Востока этот показатель существенно превышает среднероссийский уровень (в 2015-2017 гг. он составлял 32,6-31,9\%). Наиболее тяжелая ситуация по этому индикатору складывается в Чукотском АО (47,6-48,5\% убыточных предприятий в 2015-2017 гг.), в Еврейской АО (47,6-47,4\%), Забайкальском крае $(47,1-41,6 \%)$ и Магаданской области $(40,9-38,3 \%)^{21}$.

Мы разделяем мнение коллег, что формирование в Дальневосточном макрорегионе надежных условий для стабильного экономического роста и благоприятной социальной среды невозможно без «институциональной трансформации бизнес-среды, ориентированной на повышение качества инвестиционных потоков с целью обеспечения реального экономического роста и повышения благосостояния граждан» [Глазырина и др., 2018. С. 108]. Всё это указывает на необходимость и важность более «тонкой настройки» целей и реальных механизмов экономического развития отдельных субъектов РФ с общими амбициозными задачами Национальной программы, формируемой в настоящее время для Дальневосточного макрорегиона.

\section{Литература}

Антонова Н.Е., Волков Л.В., Сухомиров Г.И. Биоресурсный сектор Дальнего Востока России // Пространственная экономика. 2017. № 2. С. 110-137. DOI: $10.14530 / \mathrm{se} .2017 / 2.110-137$.

\footnotetext{
${ }^{20}$ По данным Росстата [Эл. ресурс]. Официальный сайт. URL: http:/www.gks.ru/wps/ wcm/connect/rosstat_main/rosstat/ru/statistics/publications/catalog/4890740049342bcf865 $7 \mathrm{de} 3 \mathrm{fbd} 401489$ (дата обращения: 25.03.2019).

${ }^{21}$ По данным Росстата [Эл. ресурс]. Официальный сайт. URL: http:/www.gks.ru/wps/ wcm/connect/rosstat_main/rosstat/ru/statistics/publications/catalog/4890740049342bcf865 7de3fbd401489 (дата обращения: 25.03.2019).
} 
Антонова Н.Е., Ломакина Н.В. Природно-ресурсные отрасли Дальнего Востока: новые факторы развития // Экономические и социальные перемены: факты, тенденции, прогноз. 2018. Т 11. № 1. С. 43-56. DOI: 10.15838/ esc/2018.1.55.3

Бардаль А.Б., Демьяненко А.Н., Дёмина О.В., Дёмина Я.В., Ломакина Н.В., Минакир П.А. К вопросу о трёхстороннем экономическом сотрудничестве Республики Корея, КНДР и России // Регионалистика. 2018. Т. 5. № 6. С. 18-36. DOI: $10.14530 / \mathrm{reg} .2018 .6 .18$.

Белан А.К., Шмат В.В. Анализ влияния ресурсных и нересурсных факторов на рост экономики Томской области с применением когнитивного подхода // Вестник НГУ. Серия: Социально-экономические науки. 2015. Т. 15. Вып. 1. С. 78-93.

Глазырина И. П., Лавлинский С.М. Трансакционные издержки и проблемы освоения минерально-сырьевой базы ресурсного региона // Журнал новой экономической ассоциации. 2018. № 2 (38). С. 121-143.

Глазырина И.П., Фалейчик А.А., Фалейчик Л.М. Инвестиции и экономическое развитие: сравнительный анализ для регионов России // Вестник Забайкальского государственного университета. 2018. Т. 24. № 8. С. 101-111. DOI: $10.21209 / 2227-9245-2018-24-8-101-111$.

Дондоков З.Б.Д. О Стратегии-2035 и инструментах социально-экономического развития Республики Бурятия // Вестник Бурятского научного центра Сибирского отделения Российской академии наук. 2018. № 3 (31). С. 105-112. DOI: $10.31554 / 2222-9175-2018-31-105-112$.

Дондоков З. Б.Д., Потапов Л. В., Кислов Е.В. Основные направления и проблемы развития минерально-сырьевого сектора Республики Бурятия // География и природные ресурсы. 2019. № 1. С. 137-145. DOI: 10.21782/ GIPR0206-1619-2019-1(137-145).

Дорошенко С.В., Шеломенцев А. Г. Сырьевой сектор: фактор развития или торможения национальной экономики // Современные технологии управления. 2015. № 3 (51). Номер статьи: 5106. Дата публикации: 2015-03-08. URL.: http:// sovman.ru/articl /5106 (дата обращения: 15.02.2019).

Крюков Я.В., Самсонов Н.Ю., Яиенко В.А Российская редкоземельная промышленность: следует ли перенять опыт Китая? // ЭКО. 2018. № 10 (532). C. $138-152$.

Ломакина Н.В. Государственное стимулирование инвестиций в минерально-сырьевые проекты: дальневосточный вариант // Регионалистика. 2018. Т. 5. № 4. C. 14-23. DOI: 10.14530/reg.2018.4.14.

Минерально-сырьевой сектор Азиатской России: как обеспечить социально-экономическую отдачу / Под ред. акад. РАН Кулешова В.В. Новосибирск: ИЭОПП СО РАН, 2015. 352 с.

Михеева Н.Н. Факторы роста российских регионов: адаптация к новым условиям // Регион: экономика и социология. 2017. № 4 (96). C. 151-176. DOI: 10.15372/REG20170407.

Природный капитал региона и российско-китайские трансграничные отношения: перспективы и риски / Под ред. И. П. Глазыриной, Л. М. Фалейчик. Чита: ЗабГУ, 2014. 527 с..

Ресурсные регионы России в «новой реальности» / Под ред. акад. В. В. Кулешова. Новосибирск: Изд-во ИЭОПП СО РАН, 2017. 308 с. 
Российский Дальний Восток на пути в будущее / Под ред. П. А. Минакира; Институт экономических исследований ДВО РАН. Хабаровск: ИЭИ ДВО РАН, 2017. 395 c.

Самсонов Н. Ю. Глобальные цепочки поставок редкоземельных и редких металлов как высокотехнологичного сырья в рамках международной кооперации // Пространственная экономика. 2018. № 3. C. 43-66. DOI: 10.14530/ se.2018.3.043-066.

Gylfason, T., Herbertsson T., Zoega G. A Mixed Blessing: Natural Resources and Economic Growth // Macroeconomic Dynamics, 1999, 3, June. P. 204-225.

Sachs, J., Warner A. Natural Resource Abundance and Economic Growth / NBER Working Paper, No. 5398, Cambridge, Massachusetts, December 1995. [Эл. pecypc]. URL: https://www.nber.org/papers/w5398 (дата обращения: 03.03.2019).

Статья поступила 14. 04. 2019

Для цитирования: Ломакина Н.В. Стратегические приоритеты экономического развития и "ресурсная экономика» Дальневосточного макрорегиона// ЭКО. 2019. № 7. C. 35-53. DOI: 10.30680/ECO0131-7652-2019-7-35-53

\section{Summary}

Lomakina, N.V., Doct. Sci. (Econ.), Economic Research Institute FEB RAS, Khabarovsk

Strategic Priorities of Economic Development and "Resource Economy" of the Far East Macroregion

Abstract. The article investigates strategic documents of long-term development of subjects within the Far East macroregion revealing structural priorities and industries driving economic growth there. The author demonstrates that in the next 15-20 years resource extraction industries, first of all in the mineral sector, will remain the key directions of development for the majority of territories of the Far East macroregion. This assertion underlies some socio-economic indexes reflecting insufficient contribution of the resource sector to the quality of life and economic growth in the region. The author suggests a necessity to change the current state policy in the mineral sector of the Far East For in order to increase efficient use of mineral resources. It is necessary to transfer emphasis from support of production of resources to stimulation of hi-tech productions based on their use in the region. Such production can become a basis for international centers of cooperation in the Northeast Asia. It can provide coordination of objective opportunities for development of the region with priorities from the expected National program for the Far East. Besides, it will improve contribution of mineral resources to social and economic development of the region and the quality of its economic growth.

Keywords: Far East macroregion; development strategies; structural priorities; industries of specialization; drivers of growth; quality of development; mineral sector; mining industry; development potential 


\section{References}

Antonova, N.E., Volkov, L.V., Suhomirov, G.I. (2017). Bioresource Sector of the Russian Far East. Prostranstvennaja jekonomika [Spatial Economics]. No. 2. Pp. 110-137. DOI: 10.14530/se.2017/2.110-137. (In Russ.).

Antonova, N.E., Lomakina, N.V. (2018). Natural Resource-Based Industries of the Far East: New Drivers of Development. Jekonomicheskie i social'nye peremeny: fakty, tendencii, prognoz. Economic and Social Changes: Facts, Trends, Forecast. Vol 11. No. 1. Pp. 43-56. DOI: 10.15838/esc/2018.1.55.3. (In Russ.).

Bardal', A.B., Dem'janenko, A.N., Djomina, O.V., Djomina, Ja.V., Lomakina, N.V., Minakir, P.A. (2018). About the Trilateral Economic Cooperation of Republic of Korea, DPRK and Russia. Regionalistika. Vol. 5. No. 6. Pp. 18-36. DOI: 10.14530/ reg.2018.6.18. (In Russ.).

Belan, A.K., Shmat, V.V. (2015). The analysis of influence of resource and not resource factors on growth of economy of the Tomsk region with application of cognitive approach Vestnik Novosibirskogo gosudarstvennogo universiteta. Serija: Social'no-jekonomicheskie nauki. Vestnik of NSU. Series: Social and Economic Sciences. Vol. 15. No 1. Pp. 78-93. (In Russ.).

Glazyrina, I.P., Lavlinskij, S.M. (2018). Transaction Costs and Problems in the Development of the Mineral and Raw-Material Base of the Resource Region. Zhurnal novoj jekonomicheskoj associacii. The Journal of the New Economic Association. No. 2 (38). Pp. 121-143. (In Russ.).

Glazyrina, I.P., Falejchik, A.A., Falejchik, L.M. (2018). Investment and Economic Development: Comparative Analysis for Russian Regions. Vestnik Zabajkal'skogo gosudarstvennogo universiteta. Transbaikal State Univercity Journal. Vol. 24. No. 8. Pp. 101-111. DOI: 10.21209/2227-9245-2018-24-8-101-111. (In Russ.).

Dondokov, Z.B.-D. (2018). The Strategy-2035 and Instruments of Social and Economic Development of the Republic of Buryatia. Vestnik Burjatskogo nauchnogo centra Sibirskogo otdelenija Rossijskoj akademii nauk. No. 3 (31). Pp. 105-112. DOI: 10.31554/2222-9175-2018-31-105-112 (In Russ.).

Dondokov, Z.B.-D., Potapov, L.V., Kislov, E.V. (2019). Main Directions and Problems of Development of the Minerals and Raw Materials Sector in the Republic of Buryatia. Geografija i prirodnye resursy. Geography and Natural Resources. No. 1. Pp. 137-145. DOI: 10.21782/GIPR0206-1619-2019-1(137-145) (In Russ.).

Doroshenko, S.V., Shelomencev, A.G. (2015). Raw sector: factor of development or braking of national economy. Sovremennye tehnologii upravlenija.Modern Technologies of Management. Vol. 5. No. 3. No. paper: 5106. Available at: http:// sovman.ru/articl /5106/ (accessed 15.02.2019). (In Russ.).

Kryukov, Ja.V., Samsonov, N. Ju., Yatsenko, V.A. (2018). Russian Rare Earth Industry: Should China's Experience be Adopted? ECO. No. 10 (532). Pp. 138-152. (In Russ.).

Lomakina, N.V. (2018). Government Promotion of Investment in Mineral and Raw Materials Projects: Far Eastern Case. Regionalistika. Vol. 5. No. 4. Pp. 14-23. DOI: $10.14530 /$ reg.2018.4.14. (In Russ.).

Mineral and Raw Sector of Asian Russia: How to Provide Social and Economic Return. (2015). V.V. Kuleshov. Novosibirsk: IJeOPP SO RAN Publ, 352 p. (In Russ.). 
Miheeva, N.N. (2017). Factors of Growth of Russian Regions: Adaptation to New Conditions. Region: jekonomika i sociologija. Regional Research of Russia. No. 4 (96). Pp. 151-176. DOI: 10.15372/REG20170407 (In Russ.).

Natural Capital of the Region and Russian-Chinese Cross-border Relations: prospects and risks. (2014). I. P. Glazyrina, L. M. Falejchik. Chita: ZabGU Publ. 527 p. (In Russ.).

Resource Regions of Russia in "New Reality». (2017). V. V. Kuleshov. Novosibirsk: IJeOPP SO RAN Publ., 308 p. (In Russ.).

The Russian Far East: on The Way to Future. (2017). P.A. Minakir. Habarovsk: IJeI DVO RAN Publ. 395 p. (In Russ.).

Samsonov, N. Ju. (2018). Global Chains of Supply of Rare-Earth and Rare Metals as High-Tech Raw Materials Within the Framework of International Industrial Cooperation. Prostranstvennaja jekonomika.Spatial Economics. No. 3. Pp. 43-66. DOI: 10.14530/se.2018.3.043-066. (In Russ.).

Gylfason, T., Herbertsson, T., Zoega, G. (1999). A Mixed Blessing: Natural Resources and Economic Growth. Macroeconomic Dynamiks. No.3. June. Pp. 204-225.

Sachs, J., Warner, A. (1995). Natural Resource Abundance and Economic Growth. NBER Working Paper, No. 5398, Cambridge, Massachusetts. Available at: https://www.nber.org/papers/w5398 (accessed 03.03.2019).

For citation: Lomakina, N.V. (2019). Strategic Priorities of Economic Development and "Resource Economy" of the Far East Macroregion. ECO. No. 7. Pp. 35-53. (In Russ.). DOI: 10.30680/ECO0131-7652-2019-7-35-53 